\title{
Pedagogy of the Dispersed: A Cost-Benefit Analysis of the African Diaspora Phenomenon through the Human and Social Capital Lens
}

\author{
Dr. Charles Kivunja ${ }^{1}(\mathrm{PhD}) \&$ Associate Professor Edward Shizha ${ }^{2}(\mathrm{PhD})$ \\ ${ }^{1}$ Senior Lecturer in Pedagogy and Educational Leadership, Researcher: Embedding Social Media Technologies in \\ Pedagogy, Manager Leximancer Qualitative Software, School of Education, The University of New England, \\ Armidale, 2351, New South Wales, Australia \\ ${ }^{2}$ Associate Professor in Society, Culture and Environment \& Youth and Children's Studies, Wilfrid Laurier Univesity, \\ 73 George Street, Brantford, ON, N3T2Y3, Canada \\ Correspondence: Dr Charles Kivunja, Senior Lecturer in Pedagogy and Educational Leadership, School of Education, \\ The University of New England, Armidale, 2351, NSW, Australia. Tel: 61-412-466-184 E-mail: \\ ckivunja@une.edu.au; c.kivunja@bigpond.com
}

Received: March 21, 2015

doi:10.5430/ijhe.v4n2p159
Accepted: March 31, 2015

Online Published: April 1, 2015

\begin{abstract}
With its origin in Greek where 'diaspora' as a noun means 'a dispersion' or as a verb means to 'scatter about', the term is used in this paper to refer to the dispersion or scattering of Africans from their original African homeland and now live in countries other than their own. Indeed some Africans have dispersed from their own countries to other countries in Africa. For the purposes of this paper our analysis focuses on Africans who live outside Africa. This paper explores the African diaspora phenomenon starting from the commercial extraction of Africans as resources to serve as inputs into plantain development in North America and manual labourers in Europe, South America and the Caribbean, to the colonial exploitation of African peoples during the 'Scramble for Africa', to political exiles and economic refugees that ensued, following political independence and instabilities, and to expert skilled migrations of Africans abroad, including digital diaspora. Grounded in the educational philosophy of human and social capital theory, the paper presents a cost benefit analysis of the gains and losses that Africans and African countries have experienced as a result of the African diaspora phenomenon. The analysis leads to the philosophical conclusion that whereas the initial dispersion of Africans to overseas countries represented a significant cost to the human and social capital of Africa, African diaspora in the $21^{\text {st }}$ century have potential to improve the human and social capital not only for themselves and their former homeland, but also in the host countries.
\end{abstract}

Keywords: Pedagogy of diaspora, African diaspora, Colonial exploitation, Scramble for Africa, Human and social capital, Transnationalism

\section{Introduction}

\subsection{Defining the African Diaspora Phenomenon}

Let's start this analysis with an articulation of what we mean by diaspora. Diaspora can generally be defined as "national migrant communities living in interaction among themselves and with their country of origin" (Assogba, 2002, p. 101). The African diaspora in particular have been defined as "people of African origin living outside of the continent, irrespective of their citizenship and nationality, and who are willing to contribute to the development of the continent and the building of the African Union" (Tölölyan, 1996, p.3). The diaspora are linked to transnationalism; practices in which immigrants engage in exchanges, connections and practices across borders (International Organization for Migration [IOM], 2010) as well as among themselves in the countries where they have settled. Transnationalism is a feature of the diaspora, which implies being connected to several places at once or "being neither here nor there" (IOM, 2010, p.1) - a defining element of the experience of being a migrant. The term diaspora cannot be defined or explained without making reference to transnationalism that creates migrants who in turn form the diaspora community. Vertovec (2006) suggests that diaspora are self-identified ethnic groups, with specific places of origin, which have been globally dispersed through voluntary or forced migration. In the context of the African diaspora, it is a label that describes the dispersed people who were/are removed or exiled from Africa. Central to the notion of diaspora is a continued identification with the country of origin: an attachment that facilitates 
the transfer of resources and ideas from the country of destination to the country of origin (Crush et al., 2013). On another level, these resources can also be utilized by members of the diaspora to support one another in a country that may be hostile to their presence. As Faist (2010) argues:

Although transnationalism and the diaspora refer to cross-border processes, diaspora has been often used to denote religious or national groups living outside an (imagined) homeland, whereas transnationalism is often used both more narrowly - to refer to migrants' durable ties across countries - and, more widely, to capture not only communities, but all sorts of social formations, such as transnationally active networks, groups and organisations. (p. 9)

While some critics would want to separate the diaspora from transnationalism, our argument is that the two are immutable and inseparable; they are a result of migration and have a common effect on the immigrants' social, political and economic practices and their connections within the host nation and to their home countries.

The diaspora established social formations, such as intergroup and intragroup engagements, social networks of ethnic groups and communities associations or organizations are used as forms of social support. The formations are important in retaining homeland ties and the incorporation of immigrants into the regions of destination (Faist, 2010). Community associations are used as a way of maintaining collective memories and cultural identities that connect members to a sense of common identity which the Africans in the diaspora are likely to lose through integration or assimilation into the dominant society. Therefore diaspora is a practice (Adamson \& Demetriou, 2007), a stance (Brubaker, 2005), or a discourse (Van Hear, 2012) that is politically and socially constructed. As Betts and Jones (2012) noted, "It is subject to a process of contestation over insider/outsider boundaries and orientation, and can intersect with other organisations and identity categories in complex ways" (p. 6).

With the emergence of migration and transnationalism, globalisation has made immigrants question their identity and allegiance or loyalties. This is particularly so for African diaspora who experience identity crisis in receiving countries because of their culture and skin pigmentation. On the one hand, for some, their experiences of racism, discrimination and marginalisation remind them that they do not belong to the host country. Furthermore, for others, their economic participation and acquisition of citizenship give them a feeling of entitlement and belongingness to the country of settlement. Thus the diaspora thesis focuses not only on the relationship between dispersed people (Dufoix, 2008), but also relationship with both their home countries and destination countries. African immigrants in the diaspora develop multiple trans-identities and uncertainties about belongingness that encourage them to build multiple social, economic and cultural relations across geographic and or political boundaries (Cohen, 2011) particularly so for knowledge diaspora networks consisting of highly skilled immigrants. In that respect, the African diaspora is a type of political and cultural consciousness that produces multiple and overlapping identities that African immigrants in the global society now possess. According to Chiang (2010), the mobility and displacement of immigrants destabilizes their traditional sense of identity that was deeply rooted in a sense of community and nation-state. The newly created global and multilayered identities and multiple communities threaten the African self-definitions and create feelings of isolation and marginalization in the host nations.

The purpose of this paper is to use the educational philosophy of human and social capital theory to present a well-informed cost benefit analysis of the gains and losses that Africans and African countries have experienced as a result of the African diaspora phenomenon.

\section{Contextualising the Phenomenon: Factors Responsible for the Diaspora}

Broadly speaking, the diaspora formation results from immigration and can be traced through three main factors which are historical, political and economic. While, there is abundant literature that discusses the idea of the diaspora within political and economic realities, not much is available in respect of the historical formations of the African diaspora.

\subsection{Historical Factors}

The African diaspora emerged because of historical events that led to the relocation (forced and voluntary) of Africans from the African continent mainly to Europe and North America. There are numerous events that are historical that led to the dispersal of Africans from their homelands.

\subsubsection{The victim diaspora}

Colin Palmer (2000) identified the movements of Africans as associated with the Indian Ocean trade to Asia, the Atlantic slave trade to the Americas (Europe was not an exception to the slave trade), and the contemporary movement to various parts of the globe. In the $18^{\text {th }}$ century Africans were forcibly shipped and imported as slaves 
across the Atlantic to North America, South America and the Caribbean to work on the cotton, tobacco and sugar plantations. Slavery resulted in the emergence of probably the first African diaspora in Europe and the Americas, which Cohen (2008) describes as the 'victim diaspora' that experienced traumatic interludes in their histories which led to their dispersion or further dispersion. Slavery victimized and dislocated around 12 million (Segal, 1995) or 15.4 million (Inikori, 1982) Africans from their familiar social and cultural milieu where they had close reciprocal community relations that supported their economic, social and mental wellbeing. On landing in foreign lands, the imported Africans could not maintain contact with their motherland and could not establish social networks or economic activities that connected them to their homelands. Nonetheless, they maintained social and cultural connectivities and supports under extreme inhuman conditions in which they were treated as commercial goods to be disposed or resold at the whim of the slave "owner". For Africans, being owned, commercialised, merchandized and marketed on the auction floor as products or goods for profit emasculated their sense of being and humanity. The branding and metal collars or bracelets that were attached to them had the evident intention of making clear that the slave was a commodity, not a person. This was probably the first African diaspora community outside of Africa (notwithstanding Africa's experience of slave trade and forced migration during the Islamic hegemony of the $7^{\text {th }}$ and $8^{\text {th }}$ centuries). While the slave trade had a huge impact on the forced movement and translocations of Africans from Africa to the Americas and Europe, colonization produced another form of an African diaspora.

\subsubsection{The diaspora of colonization}

The period 1881 to 1914 witnessed what became known as the "Scrambe for Africa or Partition of Africa" (Brantlinger, 1985, p. 9). During those 33 years European powers invaded, occupied, colonised and annexed African countries. The process was so ruthless and aggressive such that whereas in 1870 only 10 percent of Africa had been colonised, by 1914 practically the whole continent had been aportioned among the seven scramblers, namely Britain, France, Belgium, German, Portugal, Italy and Spain (Brantlinger, 1985). The 10 percent that escaped the stampede were modern day Ethiopia, which was then called Abyssinia, in the horn of Eastern Africa, and Liberia on the western coast of what the colonisers referred to as the Dark Continent (Brantlinger, 1985). To prevent war among the colonisers and to make the scramble less chaotic, a conference generally referred to as the Berlin Conference of 1884 was held to regulate the political and economic rivalries among the new 'owners' of Africa.

The colonial period, from the mid-19th century up until the 1960s for some countries and 1980s for others, contributed to creating strong, although very unequal, trade ties between Africa and Europe. In particular, the colonial process contributed to the exploitation of the African countries, thereby creating cultural and economic bonds which later on facilitated migrations and the creation of an African diaspora of colonization in Europe. That period included students who went to study abroad and stayed, and many others who migrated and became citizens. As a result, an important part of the African diaspora can be found in European countries that had colonial history. The African diaspora of colonization was followed by the diaspora of decolonization which includes Africans who relocated overseas during and after the struggles for independence.

\subsubsection{Diaspora of decolonization}

Early post-independence, starting from the $1950 \mathrm{~s}$, there was increased migration from Africa to Europe, creating the conditions for the settlement of an active African diaspora (Zeleza, 2008). Despite gaining political independence, economic and cultural ties remained strong between the two regions, especially with the old colonist countries. This period marked a rather important increase in emigration aimed at acquiring better quality of life and education. This diaspora is mainly the product of "voluntary migrations".

\subsubsection{The digital diaspora}

Recently, there has been an extensive use of digital connections that have spread information at vast speeds and have enabled individuals to share information and also easily get information on immigration. Communication technology has increased the prospects of people immigrating resulting in what Everett (2009) calls the digital diaspora, the e-diaspora or virtual diaspora. The reliance on the Internet, social media, and other forms of digital media communication helps the African diaspora maintain connections and social networks with friends, relatives and other associates both in the diaspora and at home.

\subsection{Political factors}

Starting from the 1980s, the most common grounds on which Africans left their countries changed in nature. Fleeing from wars, poverty or political persecution became a major cause of emigration (Omeje, 2007). Political conditions in both the pushing and receiving countries, such as relative political stability, rule of law and human rights and freedoms in the receiving countries influenced the flow of political immigrants. 
At this political level, the conceptualization of the African diaspora comprises those who left Africa out of fear of pervasive violence, persecution and oppression. During the Nigerian civil war, for example, many people from Biafra migrated to Western countries. This migration process was also observed during the Liberian civil war, the Somalian conflict, the Eritrean-Ethiopian war (Mufson, 2000) and recently the Arab Spring in Libya, Tunisia and Egypt. Wars tend to create more immigration, as well as huge refugee populations that separate family members and relatives, and destroy communities and social cohesion. The 1951 Convention Relating to the Status of Refugees defines a refugee as:

A person who owing to a well-founded fear of being persecuted for reasons of race, religion, nationality, membership of a particular social group or political opinion, is outside the country of his nationality and is unable or, owing to such fear, is unwilling to avail himself of the protection of that country; or who, not having a nationality and being outside the country of his former habitual residence as a result of such events, is unable or, owing to such fear, is unwilling to return to it .... (Blake, 2010, p. 72)

Human rights violations and repression (for example, in Zimbabwe in recent years) generate the desire to migrate as political asylum seekers. For instance, during apartheid in South Africa, many anti-apartheid activists fled to the West. Similarly, political activists who oppose dictatorship in Africa have fled to find refuge in foreign countries to become "exile diasporas" or what Dufoix (2008) refers to as an "exile polity" - a political space formed by groups who mobilize in opposition to the current regime of their country. Exiles are those who are pushed out of their country of origin for political reasons and sometimes feel threatened even if they are living in foreign lands. In May of 2011, for example, the British police issued warnings to two Rwandan nationals living in London that they faced an 'imminent threat' of assassination at the hands of the Rwandan government (Siddique, 2011) because they were exiled former military officers who had founded the Rwanda National Congress, a new political party of exiles challenging the Rwandan political leadership (Betts \& Jones, 2012).

According to Ajibewa and Akinrinade (2003), while the continent's share of the global refugee and human displacement problem has declined in recent years, both in relative and absolute terms, Africa has continued to produce a disproportionate share of the world's refugees in relation to its overall population. The armed conflicts, lack of good governance and rule of law, and lack of respect for human rights are the root causes of refugee flows and other forms of forced displacement (Shizha, 2014).

Some individuals leave their established careers behind to join the ranks of world refugees whose daily survival depends on paltry handouts from government agencies and charity organisations. This experience of living on the margins destabilises a previously unquestioned identity and grossly disables them (Okeke-Ihejirika, 2015). Credentials that provided an enviable status and solid means of living back in the country of origin now appear worthless in the new job market in the country of refuge. This is particularly so in countries such as Canada where foreign educational credentials and work experience are not recognised by employers. Refugees generally face more difficult prospects in reconstructing identities given their experience of 'forced' and unprepared exit. They are often reduced to 'beggars' in a new homeland where 'welfare' has become a central aspect of social organisation that humiliates them (Okeke-Ihejirika, 2015).

\subsection{Economic Factors}

The push factors that lead to economic migration include a lack of life chances, lower living standards, lack of available opportunities to gainfully utilise skills in the home country, and economic stagnation or depression (Shizha, 2014). The relative advantageous conditions in host countries act as pull factors, for example, higher wages, job opportunities and good working conditions. While early postcolonial migrants from Africa moved to Western countries as students who would return home (while others stayed) after acquiring their new educational qualifications, the later wave was motivated by purely economic considerations. In the 1980s, 1990s and 2000s, a new wave of African immigrants was a result of structural adjustment programs (SAPs) that were introduced by African governments as a result of the strict conditions imposed by the World Bank and International Monetary Fund (IMF) as necessary preconditions for advancing loans to poor countries whose economies were struggling for growth. SAPs forced governments to implement neoliberal economic reforms through restructuring their economies; cutting budgetary expenditure on social services, introducing labour layoffs, devaluing local currencies and introducing the open market system that was not favourable to local businesses. SAPs led to high unemployment rates and general poverty in African countries. The severe breakdowns in the economic sphere continued and still continue to make it more difficult for people in Africa to survive and remain in their countries (Ajibewa \& Akinrinade, 2003). Arguing on the relationship between neoliberal policies and migration, Munck (2010) states: 
The neoliberal narrative posits a mutually beneficial relationship between migration and development, indeed that has been a major theme in recent global migration debates and policy formulation. The sending country is seen as the major beneficiary and, overall, migrants are seen as a burden on and even a threat to the affluent North. What this discourse seeks to bury is any critical understanding of the root causes of global labour migration and its roots in uneven development and the continued subjugation of the South by the dominant capitalist regimes, not least through the active policies of neoliberal globalisation. (p. 6)

Neoliberal globalisation benefits the North through the availability of a pool of cheap highly skilled labour force from Africa. Most immigrants from Africa to the Organisation for Economic Co-operation and Development (OECD) countries (especially to Europe, Australia and North America) are highly educated. However the treatment of highly qualified immigrants in the North is not a situation that the immigrants are proud of. In their new homes, their education and qualifications are not acknowledged and accepted. As a result, African immigrants find themselves underemployed, underpaid, and in some cases unemployed. For Sub-Saharan Africa, although the highly skilled emigrate out of choice, migrants represent a return to colonial era of forced labour patterns and cheap labour (Shizha, 2014). Capitalist accumulation on a world scale is currently deepening these tendencies towards the expulsion of labour from meaningful employment in the home country (by economic and financial deprivation) and discrimination and marginalisation of the same from meaningful employment in the receiving countries (due to racism and discrimination).

\section{Literature Review: A Theoretical Framework Undergirding the Cost-Benefit Analysis of the African Diaspora Phenomenon}

\subsection{Rationale for Human or Social Capital Theory}

In Distinction French sociologist Pierre Bourdieu (1984) presented groundbreaking work on what he called economic capital, cultural capital and social capital, and emphasised the role social capital played in enabling people to access resources as a result of the social networks or institutionalised relationships that people possessed. That social capital enabled people to acquire economic capital not because of what they knew but because of whom they knew. That way, social capital and the way it was accessed ensured that the rich remained rich, the elite remained in the highest echelons of society and the poor remained the wrong kind of people to enter the circles of the elites. In Bowling alone: The collapse and revival of American Community American social capital theorist Robert Putnam (2000) expressed concern about what he saw as the breakdown in social relationships in American society. This was because, with industrialisation, Americans no longer had much time to socialize with their neighbours, friends and even family because they were spending most of their time at work, commuting to work, watching TV alone and then in bed sleeping. He saw this as loss of social capital and keen to rectify this situation, he came up with ways that could enable Americans to develop the essential features of social life, based on social networks, norms, values, beliefs, trust and support. The work of these sociologists was contributed to by other scholars such as Coleman (1986a; 1986b; 1990), Szreter and Woolcock (2004), Todaro and Smith (2009), and Woolcock (2001) resulting into a well-grounded theory of human and social capital which is reviewed here because it provides an excellent lens through which to discuss the costs and benefits of the African diaspora phenomenon. As this paper analyses the costs and benefits of the African diaspora phenomenon in terms of peoples' relationships and their contributions to productivity in their communities and the economy as a whole, human and social capital theories appear to provide an excellent lens through which to conduct the analysis.

\subsection{Human or Social Capital Theory}

The earliest treatment of human capital can be traced back to Adam Smith who is a well known foundational theorist of economics. In his seminal book, The Wealth of Nations, Smith (1776) postulated that investment in people through expenditures on their education and training was investment in human capital and was comparable to investment in physical capital, such as expenditure on machines, tools and equipment used in production. Along this line of thought, human capital became any stock of innate or acquired knowledge or characteristics that an individual has and can be used to contribute to their productivity. In agreement with this early approach, more recent scholars generally use the term human capital in economics and sociological studies to refer to what Todaro and Smith (2009) call "human capacities" (p. 375) that impact upon productivity. Black and Hughes (2001) define human capital as "the knowledge, skills and health embodied in individuals" (p. 3).

Thus, human and social capital theory postulates that the accumulation of human capital is essential for increased productivity, higher incomes and sustained economic growth in any country. The theory posits the understanding that the development of such human capital occurs primarily through access to education because education contributes to the acquisition of skills and knowledge which in turn increase productivity among the educated (Harbison, 1971). 
Indeed in light of this understanding, Michael Fullan (2001) suggests, the moral purpose of education is to help build human capital by preparing individuals to be ready for engagement in productive employment after their studies.

In contrast, in its earliest application, the term social capital was used to describe the goodwill that existed between people and which could be used to build communities. The notion of social capital became more common in the latter part of the twentieth century with the contributions of Jane Jacobs (1961) in relation to urban life and the work of a French sociologist Pierre Bourdieu (1984) and American sociologist James Coleman (1988) who expanded the idea into the area of education. However, it was the work of Robert Putnam (1993a), an American political economist that made social capital a popular topic for research and policy debate. In particular Putnam (2000) made social capital a very popular topic with the publication of his seminal book entitled Bowling Alone: The Collapse and Revival of American Community. In that book, Putnam argued that even though the financial wealth of Americans and other western countries had increased, their sense of community had diminished. He interpreted this in terms of poverty in social capital.

More recently Winter (2000) defines social capital as "social relations of mutual benefit characterised by norms of trust and reciprocity" (p. 4). The World Health Organization (WHO, 1998) says it represents the degree of social cohesion which exists in communities and refers to the processes between people which establish networks, norms and social trust, and facilitate coordination and cooperation for mutual benefit. A leading scholar of this topic Michael Woolcock (1998) defined it as "the information, trust, and norms of reciprocity inhering in one's social networks" (p. 153). He argued that the concept of social capital includes the sources and the outcomes of social capital (Woolcock, 2001). Writing with human development in mind, Woolcock argued that social capital is multi-dimensional, that different combinations of these dimensions produce different outcomes and that certain conditions support the development of social capital that is supportive of human development. It more recent studies (Catts \& Ozga, 2005) social capital has come to mean the resources and benefits available to both individuals and communities. Accordingly, Catts and Ozga (2005) define social capital as "the various resources that people may have through their relationships in families, communities and other social networks" (p. 1). They refer to it as the "social glue that holds people together in families and communities and gives them a sense of belonging..." (p. 1). The emphasis on relationships aligns well with the OECD's $(2001 ; 2015)$ definition of social capital as "networks together with shared norms, values and understandings that facilitate cooperation within or among groups" (p.103). Thus, in contemporary theory, social capital describes the shared values, beliefs, understandings and networks that enable people to have faith in one another, trust each other and work collaboratively.

Woolcock $(1998 ; 2000 ; 2001)$ argued that these relationships had three dimensions which he referred to as bonding social capital, bridging social capital and linking social capital. Bonding capital is social capital that helps people to form strong bonds among members of their families, close friends and communities. Woolcock (2000) says it refers to the relationships that people normally have with others who are like them, particularly relating to family members and ethnic groups. The label bonding is quite appropriate because this type of social capital is said to prevent fragmentation of social life and helps people to build a sense of communal security, support, solidarity, togetherness and having a shared identity, culture or ethnicity. Thus, it is characterised by the norms, values and beliefs (Schein, 1997) developed and held by families and members of their communities.

Bridging capital, on the other hand, is social capital that extends further than the immediate circle of family members, friends and neighbours and reaches out to build relationships with people in the wider community, such as distant friends, workplace colleagues and broader social and professional networks. Woolcock (2000) described it as referring to the relationships we form with people who are not like us, for example, because they come from a different socio-economic class, a different generation or of a different ethnic background. He characterized bridging social capital as comprising horizontal relationships whereby extra-community relationships develop among people (Szreter \& Woolcock, 2004).

In comparison, linking capital is social capital that enables people and agencies or organizations to connect across occupational or cultural differences or differences in culture, which they would otherwise not normally form. Woolcock argued that linking social capital describes vertical relationships which are "alliances with sympathetic individuals in positions of power" (Woolcock, 2001, p. 72). This is the type of linking that brings together people of different social backgrounds, of status further up or lower down the social ladder, of different religions and varying ethnicity and enables individuals to leverage information and resources from institutions located outside the immediate reach of a particular community. 


\subsection{Relevance of Human and Social Capital Theory to the Analysis of African Diaspora}

This consideration of social capital is important in analysing the African diaspora phenomenon because it enables us to consider the outcomes of human and social capital which, according to Woolcock (1998) include norms, reciprocity, fairness and cooperation. The logical linearity of Woolcock's theorisation helps us to consider how social capital might be used to support the development and acquisition of human capital to support the efforts of people experiencing the African diaspora phenomenon in their efforts to achieve financial self-sufficiency and self-reliance abroad. The framework is also helpful in analysing the types of social capital, (bonding, bridging or linking), that African diaspora develop, lose or otherwise experience as a result of their dispersion. For example, many people in the diaspora lack the bonding effects of social capital and this has inevitable consequences on the emotional, social and economic support that they can receive. Equally importantly, Woolcock's theorization allows us to consider how these three forms of social capital impact on the costs and benefits of human capital newly acquired by the African diaspora. Bourdieu's (1984) understanding of the nasty exclusionary powers of social capital is a very useful lens in understanding how African diasporas access resources, including education, political power, social networks in what Bourdieu calls "playing the game" (Gauntlett, 2007, p. 2007) in which those that have no established social networks are powerless and inclined to remain so, with little power to influence what happens to them.

\section{The Costs and Benefits of the African Diaspora Phenomenon}

\subsection{The Costs to Africans and Africa of the African Diaspora Phenomenon Through the Lens of Bonding Social Capital}

\subsubsection{Bonding social capital costs of the African diaspora phenomenon}

African societies have cultural systems that have high levels of bonding social capital networks which they can use to resolve problems and conflicts in their communities. On the contrary, Africans in diaspora lack large accumulations of such social capital. Bonding social capital enables relatives or clan members to look after elderly parents, widowed wives and orphaned children. For the Africans in diaspora this is a significant cost they have to finance. The OECD (2015) points out that "access to information and influence through social networks also confers private benefits on individuals" (p. 104) in these bonding relationships. Africans in diaspora do not have these social networks. Moreover, the communities in which the Africans try to immerse themselves have their own established social networks which they can use to exclude the Africans and to reinforce their dominance or privilege over the Africans (OECD, 2015) thereby impacting a bonding social capital cost to the Africans in diaspora.

For the Africans, bonding social capital is a double-edged sword. If they stick together by their country of origin or tribe, they miss out on developing meaningful relationships with their new neighbours in the new countries. Moreover, this form of bonding has potential to impede social cohesions (ABS, 2002). Besides, as revealed in Putnam's (2000) work in America, while people were deeply engaged in community life between the 1960s and 1990s "there was an implied conformity so as to bond and less tolerance for racial and social difference" (ABS, 2002, p. 8). On the other hand, if Africans seek to socialise with people who refer to them as aliens, they risk rejection and abuse. This cost is illustrated further by Portes and Landolt (1996) who found that strong bonding social capital proved a big problem for African American contractors to gain access to the building industry in American cities dominated by operators of Italian, Irish and Polish descent. The African contractors were excluded by the strong bonding social capital among the Italian, Irish and Polish building contractors.

Although social capital literature tends not to put much emphasis on the role of families in the construction of capital, there is enough evidence to suggest that families play a major role in the construction of bonding social capital (Winter, 2000). As Africans have been dispersed to different countries, often leaving behind some family members, the concept and structure of their family has become distorted, making it difficult, if not impossible to create many of the normal relationships and networks that develop when families live together or in close proximity to each other.

Moreover, the maintenance of bonding social capital by the diaspora has significant financial costs. Whereas in accordance with bonding social capital it is quite common for African diaspora to send money to their families and relatives back home, the report by Watkins and Quattri (2014) found that many of the benefits are lost due to the high charges imposed by the money transfer companies, predominantly Western Union and Money Gram. They estimated that Africa loses between US $\$ 1.4$ and US\$2.3 billion annually as a result of high remittance charges which are as high as $12 \%$ and have been characterized as some kind of 'super tax'. Regarding this bonding social capital cost, Watkins and Quattri (2014) concluded, "No region faces higher charges for remittance transfers... Africa's diaspora face a 'remittance super tax' that hurts families and holds back development" (p. 7). What's more, Watkins and Quattri (2014) found that whereas charges on remittances to Africa were well above global average levels, 
remittances from within Africa to other African countries utilising money transfer corridors were some of the highest in the world. For example, Mozambique diaspora in South Africa or Ghanaian diaspora in Nigeria sending money home were charged well in excess of $20 \%$. Moreover, these authors argued that there was no justification for these exorbitant costs which, in effect, stifle the potential benefits of this source of bonding social capital.

\subsubsection{Bridging social capital costs of the African diaspora phenomenon}

Africans in diaspora lack bridging social capital and as a result suffer social exclusion because they lack contacts in their new communities to help them climb the ladders in social status. As noted by OECD (2015) "their lack of social bridges can turn them into eternal outsiders from wider society, sometimes hindering their economic progress" ( $p$. 104).

Furthermore, as noted by Putnam (1993b) bridging capital plays a role in establishing links between access to education, economic success and political participation. For example, as Coleman and Hoffer (1987) found, school parental networks brought together by bridging social capital as parents of children that attend the same school, can be a significant factor in providing a social structure that supports school activities, supports children at that school, increases enrolments and participation rates and reduces drop out rates. Because African diaspora have fewer opportunities to be involved in activities at community and state level, the lack of bridging social capital curtails their development of a sense of community ownership, access to resources in their communities and their appreciation of the relevance of quality education, and taking advantage of otherwise available resources to improve their education outcomes. It is quite common for people well connected by bridging social capital to let their colleagues know of job opportunities. This way bridging social capital can help people find jobs and contribute to the lowering of unemployment and improvement in people's welfare and well being. The lack of well developed bridging social capital among African diaspora means that they have less chance of utilising this venue to access employment and improved material welfare.

\subsubsection{Linking social capital costs of the African diaspora phenomenon}

The lack of linking social capital among diasporans means they have no or little connections with people in powerful positions. This has deleterious implications for accessing political power, participation in democratic government and accessing welfare services (such as education and health care). We know from the work of Chaplan, Choy and Whitmore (1992) that linking social capital creates opportunities for parents of different ethnic and cultural backgrounds to influence their children's attitude to schooling and completing school work. For example the cultural norms might emphasize the importance of attending school, completing homework, and promote a positive education ethic to their children that might even include the parents reading for their children and helping them with homework. Where such linking social capital is strong, parental involvement in schools helps participants to create community networks which can have a positive demonstration effect to the children that school work is valued and that it represents good civic society. As African diaspora often do not participate in these school-based networks, this represents a social cost to them, their children and their school community. Where the lack of linking social capital extends to a feeling of insecurity in a community, anti-social behaviour and even crime, this results in costs as the society increases policing to prevent crime, undertakes courtroom procedures to provide justice following criminal activities, supporting victims of crime, incarcerating offenders and repairing the physical infrastructure damaged by vandals. Moreover, these measures have a high opportunity cost as resources are diverted from other potential uses to attend to these criminal activities.

\subsection{The Benefits to Africans and Africa of the African Diaspora Phenomenon}

\subsubsection{Bonding social capital benefits of the African diaspora phenomenon}

A good example of benefits of bonding social capital arising out of the ADP is the financial remittances. Africans in diaspora often send money to their homeland to help their families and relatives pay for a wide range of expenses including food, medical bills, rented accommodation, funerals, education of children and investment in small shopping enterprises and agriculture. In times of political turmoil and tribal wars, these remittances become a lifeline for Africans experiencing such crises.

According to the Overseas Development Institute report (Watkins \& Quattri, 2014) these diasporan remittances to African countries totaled some US\$32 billion in 2013. The report found that while the remittances on the whole represented $2 \%$ of Africa's regional GDP, they constituted a significantly higher percentage in a number of countries. For example, for Nigeria, Senegal, Kenya and Sudan, the report found that remittance transfers totaled over US $\$ 1$ billion, with Nigeria being by far the biggest beneficiary. According to the World Bank (2013) Nigeria with more than US\$20 billion transfers in 2012 accounts for $68 \%$ of total transfers to the region. As illustrated in Table 1, there 
were nine Sub Saharan African countries for which remittances constituted more than 5\% of their GDP, rising to over $20 \%$ for Lesotho and Liberia.

Table 1. African diaspora contributions to GDP for the top ten countries

\begin{tabular}{clll}
\hline Rank & Country & Percent of GDP & Amount US\$ Million \\
\hline 1 & Liberia & 23.41 & 372.39 \\
2 & Lesotho & 22.64 & 601.87 \\
3 & Gambia & 15.37 & 89.25 \\
4 & Senegal & 11.43 & $1,366.85$ \\
5 & Togo & 10.61 & 320.71 \\
6 & Cape Verde & 9.13 & 176.80 \\
7 & Nigeria & 7.86 & $20,568.29$ \\
8 & Guinea-Bissau & 5.49 & 42.18 \\
9 & Mali & 5.02 & 444.45 \\
10 & Uganda & 3.69 & 976.00 \\
\hline
\end{tabular}

Source:

1) World Bank (2014). World Development Indicators.

2) World Bank (2012). Migration and remittances data: Bilateral remittances Matrix.

Thus, through this medium of bonding capital, African diaspora remittances represent a significant contribution to Africa's balance of payments. A single source of foreign exchange earnings that represents $2 \%$ of the region's Gross Domestic Product is a significant contribution especially when you consider that African countries are predominantly agrarian economies and have little comparative advantage to engage in export trade to western countries. It is noteworthy that Nigeria, an OPEC country with oil generating most of its foreign exchange, has the highest bonding capital transfers from diaspora, in absolute terms.

The Watkins and Quattri (2014) report found that remittances to Africa were rising. For example remittances from the UK alone to Africa were US\$5 billion in 2012 and were on the rise. They estimated that in total diasporan bonding capital transfers would exceed US\$41 billion in 2016 and that if the remittance charges imposed by the duopolist intermediaries, Western Union and Money Gram, were reduced from the current $12 \%$ to $5 \%$ of the transfers, this would increase transfers from the UK alone by US\$225 million. The value of this source of bonding capital is appreciated more when you consider that all western countries offering financial aid to Africa have decreased their support due to adverse financial conditions which have led to austerity measures in their own domestic economies. This means that bonding capital money transfers will play an even greater role in Africa's balance of payments in the foreseeable future.

\subsubsection{Bridging social capital benefits of the African diaspora phenomenon}

As discussed earlier, bridging social capital develops when people develop connections and relationships beyond their immediate family circle and extend their interactions horizontally with people such as work colleagues and others in their professional networks. African diaspora professionals have developed effective connections with peers in UK, Europe, the USA and Australia, resulting in gaining secure employment and leadership roles in institutions abroad. The bridging social capital connections have given them opportunities to earn incomes which in comparative real terms are much higher than those not only of their peers back home but indeed of most people in similar roles in Africa. As a result, these professionals can utilise the fruits of their bridging social capital to send money home and deliver unparalleled benefits to their people in Africa.

Even non-professional African diaspora that have successfully developed connections and found employment have opportunity to earn considerably more than their relatives back home. For example the World Bank (2010) estimated that some 414 million people in Sub-Saharan Africa lived on less than US\$1.25 a day in 2010. Considering that the non-professional minimum wage per hour was $£ 6.50$ in the UK in 2013, US\$10.40 in the USA and \$16.87 in Australia in the same year, it is clear that the African diaspora whose bridging social capital enables them to earn through gainful employment, even when the high costs of living in their new countries are taken into account, are in 
a much better financial position than the millions of their people living on less than US\$1.25 a day (World Bank, 2010).

\subsubsection{Linking social capital benefits of the African diaspora phenomenon}

African diaspora can develop vertical relationships through linking social capital by connecting and interacting with different peoples, cultures and businesses from/through which they can earn incomes to send back home. This kind of linking social capital not only supports their immediate families but it also helps their economies to diversify sources of foreign exchange reserves and to become more competitive in international trade. Moreover, it helps the countries to finance domestic investments.

Another benefit of linking social capital is the foreign exchange rates which are terribly skewed in favour of western currencies. For example, US $\$ 1.00$ buys nearly 3,000 Ugandan shillings (UGX) at the current exchange rate (5 March 2015) making a manual labourer in Uganda who is lucky to earn UGX $10,000.00$ a day earn US $\$ 3.50$ a day. Thus employed African diaspora who can develop effective alliances with people with business and commercial connections in their new western countries can utilise this linking social capital to experience large gains in their personal incomes when their earnings are repatriated. These benefits are illustrated by Watkins and Quattri (2014) who found that:

Average incomes in the UK are 22 times higher than in Tanzania. Average incomes in the Democratic Republic of Congo are around 1\% of those in Belgium. Incomes in France are 48 times higher than in Niger. Unsurprisingly, against this backdrop, the average annual remittance sent by an African migrant from the OECD in 2009 was greater than average annual per-capita income in Sub-Saharan Africa. (p. 12)

These statistics indicate that through successful linking social capital connections in their new homes, African diaspora can free themselves from a life of poverty to one of better financial status. Thus, linking social capital can help reduce the income inequalities and disparities between African countries and western countries. This was well articulated by Watkins and Quattri (2014) in their assertion that "migration, far more than aid or even trade, has potential to act as a force for a more equitable pattern of globalisation" (p. 12).

\section{Conclusion: Social-economic and policy implications}

As we try to analyse the African diaspora phenomenon as a human experience, we discover three dimensions that are the essence of human or social capital theory. Accordingly, to understand this phenomenon we must seek its three constitutive elements of bonding capital, bridging capital and linking capital. The work by leading sociologists such as Putnam (2000) demonstrated that there exists a causal effect between social capital and economic and social well being. He proposed that social capital and economic success go together and in fact tend to reinforce each other. Similarly, he observed that less social bonding correlated to lower economic opportunities. It is reasonable to argue that because Africans in diaspora lack large accumulations of bonding, bridging and linking capital, they tend to be marginalised in the communities they find themselves in. As marginalised individuals their job opportunities are minimal and without stable jobs and reliable income streams, the chances of educating themselves and their children also diminish. This decreases their human capital which tends to commit them to an underclass that lacks both social and financial capital.

Access to human and social capital has implications for family relationships, education and training, employment, and quality of health and well being of individuals and their families. As articulated by Winter (2000), social capital is built on norms of acceptance, cooperation, trust and reciprocity. These require that social capital be nourished and developed over a reasonable period of time. This is one of the areas where most African diaspora miss out in their new communities and countries and need time to develop trustworthiness and trust, which is not easy to achieve especially when they are often treated with suspicion in their new homeland.

Studies of social capital are important because they can shed light on the potential of social capital to make positive contribution to education, wealth, health, and community safety. This analysis grounded in human and capital theory helps us to understand the social networks that Africans in diaspora have developed through bonding, bridging and linking social capital. Bonding social capital remittances involve making personal income transfers to family, relatives and friends back home in their country of origin. These transfers are beneficial to Africa and they can be viewed as a form of investment in overseas countries which generates badly needed foreign exchange for the respective African countries. Moreover, given the limited range of export products from Africa to UK, Europe, North America and Australia, these African diasporan financial transfers represent a diversification in the sources of foreign income streams and can be viewed as a form of investment in human capital (Clemens \& Ogden, 2013). 
It needs to be said that a significant limitation to the realisation of linking social capital are the legislative measures which have been adopted across Europe to restrict non-professional Africans entry into Europe. Another limitation is the economic austerity measures currently operational in several European countries. The Africans caught up in these measures can be analysed as a cost both to the European countries and to the African diaspora. But not withstanding the tightened immigration laws and the adverse economic conditions, the flow of Africans into Europe has continued and even those offered cash incentives to return have not taken up the offers.

We touched a bit on intra-Africa diaspora but even though we are aware that most migrations in Africa have involved intra-regional movements within Sub-Saharan African countries, our analysis has mainly focused on African diaspora in overseas countries. Intra-Africa diaspora movements offer opportunities for future analysis. Furthermore, we have restricted our discussion to the benefits that African diaspora derive for themselves, for their people at home, and their countries of origin. We know however, that there are also considerable benefits enjoyed by the destination countries from the African diaspora phenomenon, such as gaining relatively cheap and yet highly skilled labour, which has potential to contribute to those countries' human and social capital. These are acknowledged but lie beyond the scope of the human and social capital considerations discussed in the present paper.

\section{References}

ABS. (2002). Social Capital and Social Wellbeing: Discussion Paper, Australian Bureau of Statistics, Commonwealth of Australia, August 2002. Accessed online on 13 February 2015 at: http://www.oecd.org/innovation/research/2380806.pdf

Adamson, F. \& Demetriou, M. (2007). Remapping the boundaries of "state" and "national identity": Incorporating diasporas into IR theorizing. European Journal of International Relations, 13(4), 489-526. http://dx.doi.org/10.1177/1354066107083145

Ajibewa, A. \& Akinrinade, S. (2003). Globalisation, migration and the new African diasporas: Towards a framework of understanding. Paper presented at the International Workshop on Migration and Poverty in West Africa March 13-14, 2003, University of Sussex.

Assogba, Y. (2002). Diaspora, mondialisation et développement de l'Afrique. Nouvelles Pratiques Sociales, 15(1), 98-110. http://dx.doi.org/10.7202/008263ar

Betts, A. \& Jones, W. (2012). The transnational exile complex: How to think about African diaspora politics. Working Paper Series No. 88, Refugee Studies Centre, University of Oxford.

Black, A. \& Hughes, P. (2001). The identification and analysis of indicators of community strength and outcomes, Canberra, Greenway, ACT: Commonewalth of Australia, Department of Family and Community Services.

Blake, J. (2010). Welcoming women: Recent changes in U.S. asylum law. Michigan Law Review First Impressions, 109(58), 71-75.

Bourdieu, P. (1984). Distinction:A social critique of the judgement of taste, London: Routledge \& Kegan Paul.

Brantlinger, P. (1985). Victorians and Africans: The Genealogy of the Myth of the Dark Continent. Critical Inquiry, 12(1), 166 - 203. http://dx.doi.org/10.1086/448326

Brubaker, R. (2005). The 'diaspora' diaspora. Ethnic and Racial Studies, 28, 1-19. http://dx.doi.org/10.1080/0141987042000289997

Catts, R. \& Ozga, J. (2005). What is social capital and how might it be used in Scotland's schools? CES Briefings, Number 36, December 2005.

Chaplan, N. Choy, M. \& Whitmore, J. K. (1992). Indochinese refuge families and acaemic achievement, Csientific American, February pp. $36-42$.

Chiang, C.Y. (2010). Diasporic theorizing paradigm on cultural identity. Intercultural Communication Studies, XIX(1), 29-46.

Clemens, M. a. \& Ogden, T. N. (2013). Migration as a Strategy for Household Finance: A research agenda on remittances, payments, and development. Financial Access Initiative (FAI) New York University working paper 10/2013. Accessed online on 5 March 2015 http://www.financialaccess.org/sites/default/files/publications/migration-as-a-strategy-for-household-finance-20 13_0.pd

Cohen, D. (2011). Braceros: Migrant citizens and transnational subjects in the postwar United States and Mexico. 
Chapel Hill: University of North Carolina Press. http://dx.doi.org/10.5149/9780807899670_cohen

Cohen, R. (2008). Global diasporas: An introduction. London, UCL Press.

Coleman, J. S. (1986a). Social Action Systems. In J. S. Coleman (Ed.), Individual interests and collective action: studies in rationality and social change (pp. 85-136). Cambridge: Cambridge University Press.

Coleman, J. S. (1986b). Social Theory, Social Research, and a Theory of Social Action. The American Journal of Sociology, 91(6), 1309-1335. http://dx.doi.org/10.1086/228423

Coleman, J. S. (1988). Social Capital in the Creation of Human Capital. The American Journal of Sociology, 94, 95-120. http://dx.doi.org/10.1086/228943

Coleman, J. S. (1990). Foundations of Social Theory. Cambridge: Belknap Press.

Coleman, J. S.\& Hoofer, T. (1987). Public and private high schools: The impact of communities. New York: Basic Books.

Crush, J., Chikanda, A., Pendleton, W., Caesar, M., Ramachandran, S., Eberhardt, C. \& Hill, A. (2013). Divided diaspora: South Africans in Canada: Special report. Waterloo, ON: Centre for International Governance Innovation and the Southern African Migration Programme.

Dufoix, S. (2008). Diasporas. Berkeley: University of California Press. http://dx.doi.org/10.1525/california/9780520253599.001.0001

Everett, A. (2009). Digital diaspora: A race for cyberspace. Albany, SUNY Press.

Faist, T. (2010). Diaspora and transnationalism: What kind of dance partners? In R. Bauböck \& T. Faist (Eds.), Diaspora and transnationalism: Concepts, theories and methods (pp. 9-34). Amsterdam: Amsterdam University Press.

Fullan, M. (2001). The new meaning of educational change. $3^{\text {rd }}$ Edition. New York: Teachers College Press.

Gauntlett, D. (2007). Creative explorations: New approaches to identities and audiences, Lonodn: Routledge.

Hanifan, L. J. (1916). The Rural School Community Centre. Annals of the American Academof Political and Social Science, 67, 130-138. http://dx.doi.org/10.1177/000271621606700118

Harbison, F. H. (1971). A Human Resource Approach to the Development of African Nations. Washington: American Council on Education.

Inikori, J. (Ed.) (1982). Forced migration: The impact of the export slave trade on African societies. London: Hutchinson University Library.

IOM, 2010. Migration and transnationalism: Opportunities and challenges. Background paper presented at the Inter-sessional Workshop of the IDM on Migration and Social Change. 19-20 July 2010.

Jacobs, J. (1961). The death and life of great American cities. New York: Random House.

Mufson, S. (2000). Eritrea won't block food aid for Ethiopia. Washington Post, Saturday, April 8, A14.

Munck, R. (2010). Migration, globalisation and development: Labour movement perspectives. Paper presented at Cumbre 2010 Human Mobility, the Promise of Development and Political Participation Conference, University of Nebraska at Omaha, May 14-15.

OECD. (2001). The Wellbeing of Nations: The Role of Human and Social Capital, Education and Skills, Paris: OECD Centre for Educational Research and Innovation.

OECD. (2015). What is social capital? Insights: Human Capital, Accessed online on 13 February 2015, at http://www.oecd.org/insights/37966934.pdf

Okeke-Ihejirika, P. (2015). Gender, contemporary realities, and the challenges of reconstructing identities in a transnational context. In E. Shizha \& L. Diallo (Eds.), Africa in the age of globalization: Perceptions, misperceptions and realities (pp. 185-199). London: Ashgate

Omeje, K. (2007). The diaspora and domestic insurgencies in Africa. African Sociological Review, 11(2), 94-107.

Palmer, C. (2000). Defining and studying the modern African: The African diaspora. African Studies Review, 43(1), 5-6. Princeton University Press.

Portes, A. \& Landolt, P. (1996). Unresolved mysteries: The Toqueville Files II. The American Prospect Online. 
Putnam, R. D. (1993a). Making democracy work: civic traditions in modern Italy. Princeton:

Putnam, R. D. (1993b). The prosperous community: social capital and public life. The American Prospect, 4(13), $35-42$.

Putnam, R. D. (2000). Bowling Alone: The collapse and revival of American community. New York: Touchstone. http://dx.doi.org/10.1145/358916.361990

Putnam, R. D. (2001). Social Capital: Measurement and Consequences. Paper presented at the The Contribution of Human and Social Capital to Sustained Economic Growth, Ottawa.

Schein, E.H. (1997). Organisational culture and leadership. San Francisco: Jossey - Bass.

Segal, R. (1995). The black diaspora: Five centuries of the black experience outside Africa. New York: Farrar, Straus and Giroux.

Shizha, E. (2014). Globalisation globalised labour markets: Migration and translocations in Sub-Saharan Africa. In E. Shizha (Ed.), Remapping Africa in the global space: Propositions for change (pp. 55-72). Rotterdam: Sense Publishers. http://dx.doi.org/10.1007/978-94-6209-836-7_5

Siddique, H. (2011). Rwandan exiles warned of assassination threat by London police. The Guardian. London, UK.

Smith, A. (1776). An inquiry into the nature and causes of the wealth of nations, Edited by R.H. Campbell and A.S. Skinner. London: Oxford University Press. http://dx.doi.org/10.1093/oseo/instance.00043218

Szreter, S., \& Woolcock, M. (2004). Health by association? Social capital, social theory, and the political economy of public health. International Journal of Epidemiology, 33(4), 650-667. http://dx.doi.org/10.1093/ije/dyh013

Todaro, M. P., \& Smith, S. C. (2009). Economic Development (10 edn.). Harlow: Addison Wesley.

Tölölyan, K. (1996). Rethinking diaspora(s): Stateless power in the transnational moment. Diaspora, 5(1), 3-36. http://dx.doi.org/10.1353/dsp.1996.0000

Van Hear, N. (2012). Forcing the issue: Migration crises and the uneasy dialogue between refugee research and policy. Journal of Refugee Studies, 25(1), 2-24. http://dx.doi.org/10.1093/jrs/fer052

Vertovec, S. (2006). Diasporas good? Diasporas bad? Centre on Migration, Policy and Society Working Paper No.41, Oxford: Oxford University.

Watkins, K. \& Maria Quattri, M. (2014). Lost in Intermediation: How excessive charges undermine the benefits of remittances for Africa, London: Overseas Development Institute.

Winter, I. (2000). Towards s Theorised Understanding of Socal Capital, Working Paper 21, Melbourne, VIC: Australian Institute of Family Studies.

Woolcock, M. (1998). Social Capital and Economic Development: Towards a Theoretical Synthesis and Policy Framework. Theory and Society, 27(2), 151-208. http://dx.doi.org/10.1023/A:1006884930135

Woolcock, M. (2000). Why should we care about social capital? Canberra Bulletin of Public Administration, pp. 17 $-19$.

Woolcock, M. (2001). The place of social capital in understanding social and economic outcomes. Paper presented at the The Contribution of Human and Social Capital to Sustained Economic Growth and Well-Being, Ottawa.

World Bank. (2010). Poverty Overview. Accessed online on 5 March 2015 at: http://www.worldbank.org/en/topic/poverty/overview

World Bank (2012). Migration and remittances data: Bilateral remittances Matrix. Accessed online on 5 February 2015 at: file:///Users/u1/Documents/African-Diaspora-Resource-Remittances-Costs-and-Benefits.pdf

World Bank. (2013). Migration and remittances team development prospects group. Migration

and Development Brief 21: Migration and Remittance Flows: Recent Trends and Outlook, 2013-2016. Available: http://tx2.cdn.caijing. com.cn/2013-118/113706465.pdf

World Bank (2014). World Development Indicators.

World Health Organisation, WHO. (1998). Health Promotion Glossary, Geneva: World Health Organisation.

Zeleza, P.T. (2008). The challenges of studying the African diasporas. African Sociological Review 12(2), 4-21. 